\title{
AEROBIC AND ANAEROBIC DEGRADATION OF TANNIC ACID ON WATER SAMPLES FROM MONJOLINHO RESERVOIR (SÃO CARLOS, SP, BRAZIL)
}

\author{
CUNHA-SANTINO, M. B., ${ }^{1}$ BIANCHINI JR., I. ${ }^{1,2}$ and SERRANO, L. E. F. ${ }^{2}$ \\ ${ }^{1}$ Programa de Pós-graduação em Ecologia e Recursos Naturais, Universidade Federal de São Carlos, \\ Rodovia Washington Luís, km 235, CEP 13565-905, C. P. 676, São Carlos, SP, Brazil \\ ${ }^{2}$ Universidade Federal de São Carlos, Departamento de Hidrobiologia, Rodovia Washington Luís, km 235, \\ CEP 13565-905, C. P. 676, São Carlos, SP, Brazil \\ Correspondence to: Irineu Bianchini Junior, Universidade Federal de São Carlos, Departamento de Hidrobiologia, \\ Rodovia Washington Luís, km 235, CEP 13565-905, C. P. 676, São Carlos, SP, Brazil, \\ e-mail: irineu@power.ufscar.br \\ Received July 11, 2001 - Accepted November 12, 2001 - Distributed November 30, 2002
}

(With 1 figure)

\begin{abstract}
In order to describe the transformations of tannic acid during its degradation (under aerobic and anaerobic conditions) incubations were performed. To evaluate the oxygen consumption, the tannic acid was added to $1 \mathrm{~L}$ of water sample from Monjolinho's reservoir $\left(22^{\circ} 00^{\prime} \mathrm{S}\right.$ and $\left.47^{\circ} 54^{\prime} \mathrm{W}\right)$; these solutions were aerated and the dissolved oxygen was monitored for 16 days, the anaerobic process was avoided. For the anaerobic and aerobic degradation, the dissolved organic carbon and the acid tannic concentrations were estimated on the samples days. The results were fitted to first-order kinetic model, being possible to verify that during the 16 days the oxygen uptake was $3.6 \mathrm{mg} \cdot \mathrm{L}^{-1}$, the deoxygenation rate $\left(\mathrm{k}_{\mathrm{D}}\right)$ of this process was 0.39 day $^{-1}$. The degradation coefficients were calculated through the decay of the tannic acid and organic carbon concentrations. In the aerobic process, the global decay coefficient $\left(\mathrm{k}_{\mathrm{G}}\right)$ was 0.36 day $^{-1}$ and in the anaerobic 0.28 day $^{-1}$. Overall, the obtained degradation coefficients suggest that the bacterioplankton of the Monjolinho's reservoir possess a high capacity of polyphenols degradation.
\end{abstract}

Key words: oxygen uptake, aerobic mineralization, anaerobic mineralization, tannic acid, Monjolinho Reservoir (UFSCar, São Carlos, SP).

\section{RESUMO}

\section{Degradação aeróbia e anaeróbia de ácido tânico em amostras de água do reservatório do Monjolinho (São Carlos, SP, Brasil)}

Tendo em vista descrever as transformações do ácido tânico durante sua degradação (sob condições aeróbias e anaeróbias), foram realizadas incubações. Para estimar o consumo de oxigênio, o ácido tânico

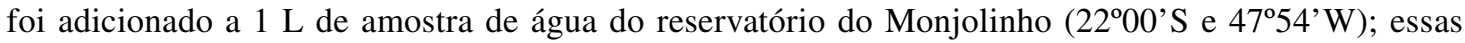
soluções foram aeradas e o oxigênio dissolvido foi monitorado durante 16 dias, sendo evitado o processo de anaerobiose. Para a degradação anaeróbia e aeróbia, as concentrações de carbono orgânico dissolvido e de ácido tânico foram periodicamente estimadas. Os resultados foram ajustados a um modelo cinético de primeira ordem, sendo possível verificar que durante os 16 dias de experimento o consumo de oxigênio foi 3,6 mg. $\mathrm{L}^{-1}$, apresentando coeficiente de desoxigenação $\left(\mathrm{k}_{\mathrm{D}}\right)$ de $0,39 \mathrm{dia}^{-1}$. Os coeficientes de degradação foram calculados por intermédio dos decréscimos das concentrações de ácido tânico e de carbono orgânico. No processo aeróbio, o coeficiente global de decaimento $\left(\mathrm{k}_{\mathrm{G}}\right)$ foi de $0,36 \mathrm{dia}^{-1} \mathrm{e}$, no anaeróbio, de $0,28 \mathrm{dia}^{-1}$. De maneira geral, os coeficientes de degradação obtidos sugerem que o bacterioplâncton do reservatório do Monjolinho possui capacidade elevada de degradação de polifenóis.

Palavras-chave: consumo de oxigênio, mineralização aeróbia, mineralização anaeróbia, ácido tânico, Reservatório do Monjolinho (UFSCar, São Carlos, SP). 


\section{INTRODUCTION}

Biodegradation is confirmed as an important mechanism of organic chemical removal in natural systems. The fate of chemicals and their partitioning over environmental systems should include complex evaluation of microbial ability to degrade (Gotvajn \& Zagorc-Koncan, 1999). Aromatic compounds, such as polyphenols comprise the second largest group of natural products, in addition to a variety of xenobiotics that are manmade aromatic pollutants (Fuchs et al., 1994). Tannins are water-soluble plant polyphenols that occur in vascular plant tissues such as leaves, seeds and flowers (Strack, 1997); they are divided into two classes: hydrolyzable and condensed (no hydrolysable). In aquatic systems, the geochemistry researches with polyphenols are virtually nonexistent, limited primarily to the monitoring of tannin leaching or degradation from leaves (Suberkropp et al., 1976). Being that tannin is one of the components of leave tissues, the plant leachates can produce several changes on the properties of the aquatic systems (such as aromaticity, carbon:nitrogen ratios, phenolic $\mathrm{OH}$, color and reactivity). Therefore, studies on its degradation and chemical interactions are necessary. Considering these potential interactions of the polyphenols in aquatic ecosystems, assays were carried out to evaluate the aerobic and anaerobic degradation of tannic acid.

\section{MATERIAL AND METHODS}

\section{Description of the study area}

The reservoir of Monjolinho (22 $02^{\circ} \mathrm{S}$ and $47^{\circ} 54^{\prime} \mathrm{W}$ ) is a small artificial water system located inside the campus of the Universidade Federal de São Carlos (SP, Brazil). Nogueira \& Matsumura-Tundisi (1994) described its morphometry; the maximum depth is $3 \mathrm{~m}$, the flooded area comprises $47.157 \mathrm{~m}^{2}$ and the reservoir has a volume of $73.251 \mathrm{~m}^{3}$. Depending on the season, the hydraulic retention time of this system varies between 2 and 23 days. Monjolinho stream provides the waters to the reservoir, the anthropic pressures on this watershed affects the water quality of this ecosystem (Marinelli et al., 2000).

\section{Experimental design}

In order to describe the degradation kinetics, solutions of tannic acid $\left(20.8 \mathrm{mg} . \mathrm{L}^{-1} \approx 11.14 \mathrm{mg} . \mathrm{L}^{-1}\right.$ in carbon basis) prepared with reservoir water (pre- filtered with glass wool) were incubated in the dark $\left(20.0^{\circ} \mathrm{C} \pm 0.6\right)$ under aerobic and anaerobic conditions, during 16 days. On sampling days $(0,1$, $2,3,4,5,6,7,10,12,14$ and 16), the concentrations of tannic acid were determined by colorimetric method (Bianchini Jr. \& Toledo, 1981) and the dissolved organic carbon by high combustion analysis with a SHIMADZU TOC-5000A analyzer. Total phosphorus (Mackereth et al., 1978), nitrate (modify from Mackereth et al., 1978) and nitrite (Strickland \& Parsons, 1960) were also determined on the incubated water samples. The degradation rates were estimated through the losses of tannic acid and organic carbon occurred during the incubation period. Oxygen uptake evaluation was also estimated (in triplicate) using a set of solutions, there was $20.8 \mathrm{mg} . \mathrm{L}^{-1}$ of tannic acid. These solutions were incubated at $20.0^{\circ} \mathrm{C} \pm 0.6$ in flasks containing filtered reservoir water. In order to maintain the solutions under aerobic conditions, they were oxygenated during 1 hour, to keep the dissolved oxygen (DO) near saturation. After the aeration, DO was measured by oxymeter (METROHM HERISAU AGCH-9100/E-637). During the experiments when the DO concentrations were below $2.0 \mathrm{mg} . \mathrm{L}^{-1}$, the solutions where aerated again, until the DO reached saturation values. Oxygen uptake was also estimated during 16 days.

The stoichiometry was related to the amount of oxygen used during the carbon oxidation. The stoichiometric coefficient of the aerobic process was calculated from the total amount of oxygen uptake and the difference between the initial and final carbon concentration. The theoretical stoichiometric (O/C relation) for tannic acid was obtained calculating the complete combustion of the substrate.

\section{Mathematical equations}

The reaction rate constants for the tannic acid degradation were calculated considering that its decay follows first-order kinetics, such as many reactions of interest in natural waters: loss of nutrients and trace metals from lakes, biological uptake, chemical precipitation and adsorption onto particles (Brezonik, 1993). A nonlinear method, Levenberg-Marquardt iterative algorithm was applied (Bianchini Jr., 1997). For aerobic conditions, it was considered that the biological oxygen depletion was directly related with the oxidation of the tannic acid (Characklis, 1990; Henze et al., 
1997; Gotvajn \& Zagorc-Koncan, 1999); from these assumptions and using equations 1 to 4 , these reactions were described as:

$$
\begin{aligned}
& \frac{d[T A]}{d t}=-k_{1}[T A]-k_{2}[T A] \\
& \frac{d[I P]}{d t}=k_{1}[T A] \\
& \frac{d[O P]}{d t}=k_{2}[T A] \\
& \frac{d[O C]}{d t}=-k_{D}[O C]
\end{aligned}
$$$$
\text { (Equation 1) }
$$$$
\text { (Equation 2) }
$$$$
\text { (Equation 3) }
$$$$
\text { (Equation 4) }
$$

where:

$[\mathrm{TA}]=$ tannic acid concentration $\left[\mathrm{mg} \cdot \mathrm{L}^{-1}\right]$, $\mathrm{t}=$ time [day],

$\mathrm{k}_{1}=$ mineralization rate constant $\left[\right.$ day $\left.^{-1}\right]$,

$\mathrm{k}_{2}=$ immobilization (microorganisms and humification) rate constant $\left[\mathrm{day}^{-1}\right]$,

[IP $]=$ inorganic products concentration $\left[\mathrm{mg} . \mathrm{L}^{-1}\right]$,

$[\mathrm{OP}]=$ organic products concentration $\left[\mathrm{mg} . \mathrm{L}^{-1}\right]$,

$[\mathrm{OC}]=$ oxygen consumption $\left[\mathrm{mg} \cdot \mathrm{L}^{-1}\right]$,

$\mathrm{k}_{\mathrm{D}}=$ deoxygenation rate constant $\left[\mathrm{day}^{-1}\right]$.

\section{RESULTS}

The aerobic and anaerobic tannic acid decay, in carbon basis and as polyphenols are shown in Fig. 1 (A, B and D). An accentuated loss of carbon from tannic acid (polyphenols amounts) was observed until the $7^{\text {th }}$ day for both aerobic and anaerobic conditions. After this period, the rate of tannic acid carbon decrease became progressively slower. Concomitantly to the tannic acid decay, the evolution of the mineralized carbon was observed. The aerobic process mineralized $6.23 \mathrm{mg} . \mathrm{L}^{-1}$ of carbon over a 16-day period. This value was $35.7 \%$ higher than that observed for anaerobic condition.

The results were fitted to first-order model that encompass two pathways for the tannic acid decay: mineralization and immobilization. The first one refers to the inorganic products (IP) and simultaneously; the second pathway is accomplished by the transformation of tannic acid into organic products (OP). The transformation yield of tannic acid into IP was $55.9 \%$ for the aerobic condition and $41.1 \%$ for the anaerobic. For the OP these values were $44.1 \%$ for aerobic and $58.9 \%$ for anaerobic condition. These values refer to IP and OP presented in Equations 2 and 3. These fittings also pointed to homogeneity of the substratum chemical composition. The kinetic fittings provide the global decay rate $\left(\mathrm{k}_{\mathrm{G}}=\mathrm{k}_{1}+\mathrm{k}_{2}\right)$ and the half-life $\left(\mathrm{t}_{1 / 2}\right)$ of the aerobic and anaerobic process; the $\mathrm{k}_{\mathrm{G}}$ values were $0.36 \mathrm{day}^{-1}\left(\mathrm{t}_{1 / 2}=\right.$ 1.88 days) for aerobic and for anaerobic conditions 0.28 day $^{-1}\left(\mathrm{t}_{1 / 2}=2.43\right.$ days $)$.

The average of total phosphorous, nitrate and nitrite concentrations were $79.1 \mu \mathrm{g} . \mathrm{L}^{-1}, 4.5$ $\mu \mathrm{g} . \mathrm{L}^{-1}$ and $3.0 \mu \mathrm{g} . \mathrm{L}^{-1}$, respectively. Fig. 1C shows the oxygen uptake during the aerobic mineralization of tannic acid. From the kinetic fitting it was possible to verify that in this process the oxygen consumption was 3.60 mg. $\mathrm{L}^{-1}$. From this fit the deoxygenation rate $\left(\mathrm{k}_{\mathrm{D}}\right)$ and the half-time of the aerobic mineralization was also obtained. The value of the $\mathrm{k}_{\mathrm{D}}$ was 0.39 $\mathrm{day}^{-1}$ that corresponds to a half-time of 1.77 days.

\section{DISCUSSION}

The decay of carbon from the tannic acid and the increase of mineralized carbon present similarities with the mineralization process of several organic substrata (McAvoy et al., 1998; Cunha-Santino \& Bianchini Jr., submitted). The trend of accentuated consumption of tannic acid carbon at the beginning of the processes, followed by stabilization, was the result of the microbial biosynthesis (particulate form) and probably from the humification processes (Golterman, 1975; Swift et al., 1979). The formation of humic susbtances from polyphenols could be a result of enzymatically oxidation to quinones or nonenzymatic polymerization of polyphenols with nitrogenous compounds (Stevenson, 1982). It can also be remarked by the disappearance of the polyphenols compounds as functional groups (Fig. 1D) and by the organic carbon remain (Figs. 1A and B) as another organic compound with different chemical characteristics than polyphenols. 

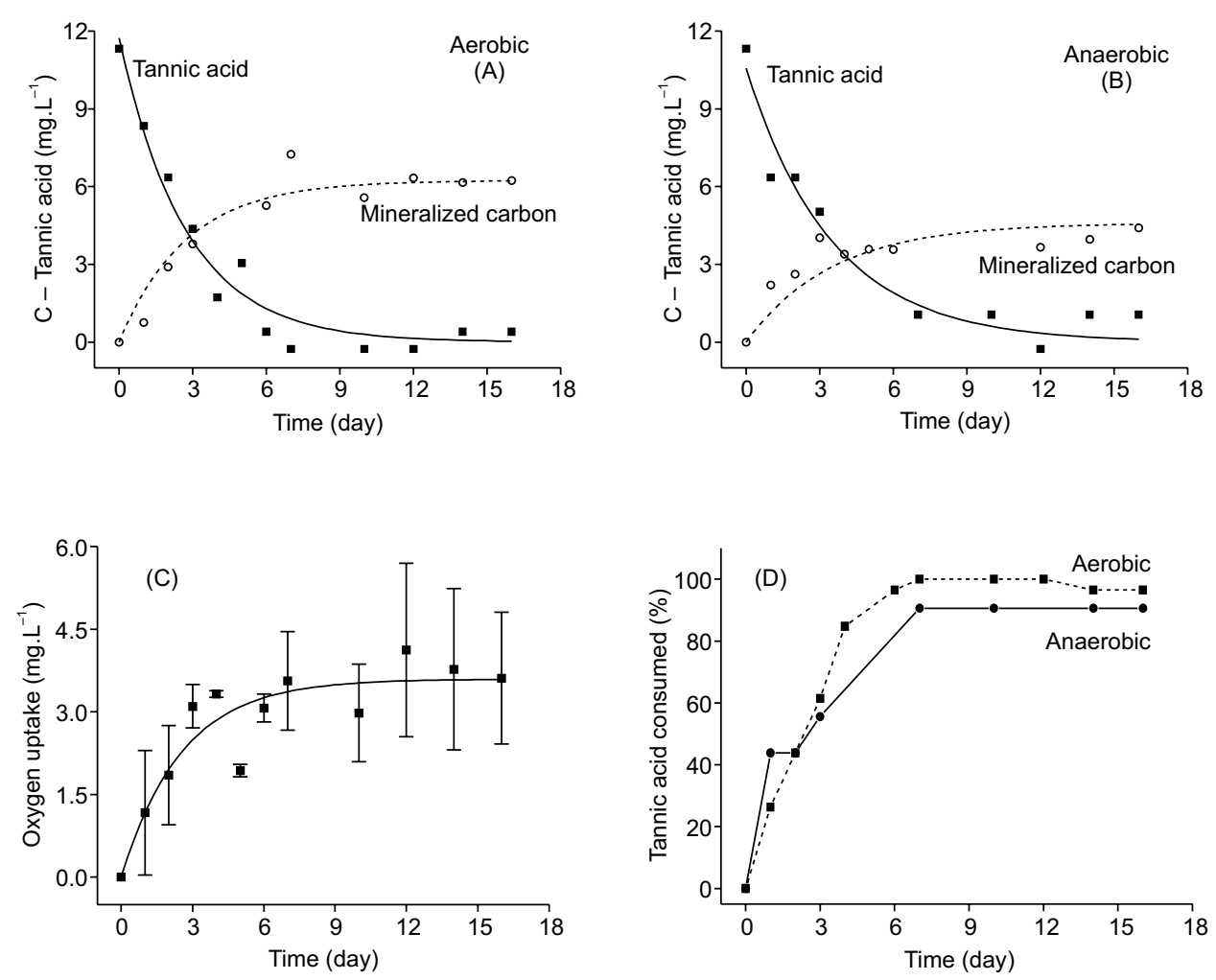

Fig. 1 - Degradation of tannic acid: carbon decay and mineralized on aerobic (A) and anaerobic (B) processes; oxygen uptake (C) and tannic acid consumption (D).

The global decay rate $\left(\mathrm{k}_{\mathrm{G}}\right)$ refers to the sum of two biogeochemical processes: immobilization (conversion into organic products) and mineralization (conversion into inorganic products). The immobilization process of the tannic acid could expressed by its assimilation by microbial cells, remained as dissolved organic carbon organic form internal recycling or as humus as discussed.

The effect of the microbial degradation in the regulation of organic compound concentrations in the aquatic ecosystems is directly related to $\mathrm{k}_{\mathrm{G}}$ and $\mathrm{k}_{\mathrm{D}}$. It is assumed that the compounds that present high mineralization rates have a high biodegradability potential. Due to the high values verified for the $\mathrm{k}_{\mathrm{G}}$, probably the polyphenols do not tend to accumulate in this reservoir. On the other hand, the compound that presents low $\mathrm{k}_{\mathrm{G}}$ values (long half-time), probably remain unaffected on the aquatic ecosystems for long periods of time, and consequently, they tend to present higher concentrations. From this assay it was possible to presume that in the reservoir of Monjolinho the aerobic biodegradation of tannic acid is higher under aerobic than anaerobic condition. The $\mathrm{k}_{\mathrm{G}}$ from the model indicates that the aerobic process was 1.28 higher than anaerobic $\left(0.286\right.$ day $\left.^{-1}\right)$. This fact is probably related to biodegradability potential of the reservoir microbiota. The adaptability of these organisms to aerobic or anaerobic immobilization and therefore, to the mineralization of tannic acid will also affect the concentrations of this compound in the environment.

The chemical or biological transformation of an organic compound presents two important parameters: (i) the stoichiometric coefficient of the process and (ii) the reaction coefficients. The stoichiometric of the mineralization process determines the extension of the same, presenting quantitative information on the consumption of the reagents and the formed products (Levenspiel, 
1974; Characklis, 1990). The stoichiometric also represents an indirect way to predict the microbial metabolic activity pathways.

A study made by Cunha-Santino \& Bianchini Jr. (submitted), on the oxygen uptake in aerobic degradation of organic compounds showed higher values of stoichiometric coefficients $(\mathrm{O} / \mathrm{C})$ during the biological oxidation of these compounds (e.g., O/C for glucose $=2.62$ and sucrose $=2.21$ ) when compared to tannic acid (0.58). The experimental stoichiometric value obtained was 3.9 times smaller than the chemical theoretical value $(\mathrm{O} / \mathrm{C}=2.3)$. The small amount of consumed oxygen probably was related to the fact that tannic acid is more resistant to breakdown. In addition, the stoichiometric value derived from the metabolic pathways during the tannic acid degradation express the predominate route used by the microorganisms and/or from partial chemicals oxidations. Considering the use of two different experimental methods, the similarity of the obtained $\mathrm{k}_{\mathrm{G}}$ and $\mathrm{k}_{\mathrm{D}}\left(0.36\right.$ day $^{-1}$ and 0.39 day $^{-1}$ ), showed that the proposed kinetic model was a robust approach for the tannic acid degradation. The decay coefficient values for the tannic acid degradation were similar to those obtained by Gotvajn \& Zagorc-Koncan (1999), experimentally. In that study the coefficient for the phenol degradation incubated with an eutrophic river water sample was 0.36 day $^{-1}$, showing the influence of nutrients ( $\mathrm{N}$ and $\mathrm{P}$ ) and organic load content on the phenol degradation in river water.

According to the phosphorous concentration, the trophic state of Monjolinho's reservoir can be characterized as eutrophic (Vollenweider, 1968). Regarding the nitrate and nitrite concentrations this system can be classified as meso-eutrophic system. The trophic state of this environment was confirmed on the studies made by Marinelli et al., 2000 on the Monjolinho watershed and by Aprile \& Bianchini Jr. (1996) in this reservoir. Considering the trophic state of this reservoir, the $\mathrm{k}_{\mathrm{G}}$ results are similar to those found by Gotvajn \& ZagorcKoncan (1999).

The low amount of consumed oxygen could be explained by the fact that tannin depressed enzyme activities and had a little effect on productivity, driving down growth efficiency of microorganisms (Foreman et al., 1998). Another study on tannic acid interaction showed that this polyphenol might lead to the formation of both soluble and insoluble aggregates with proteins. Therefore, when extracellular enzymes interact with such substances, enzymatic complexes may form with different inhibitory effects and activity levels (Rao et al., 1998). For the aquatic systems, it means that the capacity of complexation with proteins results on the interference of the enzymatic activities by microorganisms.

Overall, the rates of mineralization verified through the metabolism of the heterotrophic microorganisms suggest the capacity of this reservoir microbial community in storage or convert organic compounds. Considering the prevalence of the aerobic decay processes in the reservoir of Monjolinho, probably the tannic acid and other polyphenols could be metabolized quickly.

Acknowledgments - The authors thank Coordenadoria de Aperfeiçoamento de Pessoal de Nível Superior (CAPES) for partial support of these assays.

\section{REFERENCES}

APRILE, F. M. \& BIANCHINI Jr., I., 1996, Determinação de fósforo total em macrófitas aquáticas e no sedimento: adequação de procedimentos metodológicos. An. Sem. Reg. Ecol. VII, São Carlos, SP, pp. 47-56.

BIANCHINI Jr., I. \& TOLEDO, A. P. P., 1981, Determinação de compostos fenólicos com reagente de Folin-Denis. Ciênc. Cult., 33(4): 576-577.

BIANCHINI Jr., I., 1997, The degradation process of organic matter in reservoirs. In: L. P. Rosa \& M. A. Santos (eds.), Hydropower plants and greenhouse gas emissions. Editora Tecnologica, Rio de Janeiro.

BREZONIK, P. L., 1993, Chemical kinetics and process dynamics in aquatic systems. Lewis, Boca Raton, 754p.

CHARACKLIS, W. G., 1990, Kinetics of microbial transformations. In: W. G. Characklis \& K. C. Marshall (eds.), Biofilms. John Wiley \& Sons, New York.

CUNHA-SANTINO, M. B. \& BIANCHINI Jr., I. (Submitted) Oxygen uptake from mineralization of organic compounds on water samples of Monjolinho Reservoir (São Carlos, SP, Brazil).

FOREMAN, C. M., FRANCHINI, P. \& SINSABAUGH, R. L., 1998, The trophic dynamics of riverine bacterioplankton: relationships among substrate availability, ectoenzyme kinetics, and growth. Limnol. Oceanog., 43(6): 1344-1352.

FUCHS, G., MOHAMED, M. E. S., ALTENSCHMIDT, U., KOCH, J., LACK, A., BRACKMANN, R., LOCHMEYER, C. \& OSWALD, B., 1994, Biochemistry of anaerobic biodegradation of aromatic compounds. In: C. Ratledge (ed.), Biochemistry of microbial degradation. Kluwer Academic Publishers, Netherlands.

GOLTERMAN, H. L., 1975, Physiological limnology. Elsevier Scientific Publishing Company, Amsterdam, 480p. 
GOTVAJN, A. Z. \& ZAGORC-KONCAN, J., 1999, Biodegradation studies as an important way to estimate the environmental fate of chemicals. Water Science Technol., 39(10-11): 375-382.

HENZE, M., HARREMOËS, P., JANSEN, J. C. \& ARVIN, E., 1997, Wastewater Treatment-Biological and chemical processes. Springer-Verlag, Berlin, 383p.

LEVENSPIEL, O., 1974, Engenharia das reações químicas. Volume 1 - Cinética química aplicada. Editora Edgard Blücher Ltda, São Paulo, 211p.

MACKERETH, F. J. H., HERON, J. \& TALLING, J. F., 1978, Water Analysis: some revised methods for limnologists. Freshwater Biological Association Scientific Publication n. 36. Titus Wilson and Sons Ltd., Kendall, 117p.

McAVOY, D. C., GRADY Jr., C. P. L., BLOK, J., FEIJEL, T. C. J., FEDERLE, T. W. \& LARSON, R. J. A., 1998 Simplified modeling approach using microbial growth kinetics for predicting exposure concentrations of organic chemicals in treated waterwaste effluents. Chemosphere, 36(10): 2291-2304.

MARINELli, C. E., MORETTO, E. M., BRUCHA, G. \& LUCCA, J. V., 2000, Limnologia. In: E. L. G. Espíndola, J. S. V. Silva, C. E. Marinelli \& M. M. Abdon (eds.), A Bacia Hidrográfica do Rio do Monjolinho. RiMa Editora, São Carlos.

NOGUEIRA, M. G. \& MATSUMURA-TUNDISI, T., 1994, Limnologia de um sistema raso (Represa do Monjolinho, São Carlos, SP). I - Dinâmica das variáveis físicas e químicas. Rev. Brasil. Biol., 54: 147-159.
RAO, M. A., VIOLANTE, A. \& GIANFREDA, L., 1998, Interactions between tannic acid and acid phosphatase. Soil Science Biochem., 30(1): 111-112.

STRACK, D., 1997, Phenolic Metabolism. In: P. M. Dey \& J. B. Harborne (eds.), Plant Biochemistry. Academic Press, San Diego.

STEVENSON, F. J., 1982, Humus Chemistry. Wiley, New York, 443p.

SUBERKROPP, K., GODSHALK, G. L. \& KLUG, M. J., 1976, Changes in the chemical composition of leaves during processing in a woodland stream. Ecol., 57: 720727.

STRICKLAND, J. D. \& PARSONS, T. R., 1960, A manual of seawater analysis. Bull Fish. Res. Bel. Can., 125: 1-185.

SWIFT, M. J., HEAL, D. W. \& ANDERSON, J. M., 1979, Studies in Ecology. Decomposition in Terrestrial Ecosystems. Blackwell, Oxford, 371p.

VOLLENWEIDER, R. A., 1968, Scientific fundamentals of the eutrophication of lakes and flowing waters, with particular reference to nitrogen and phosphorous as factors in eutrophication. Paris, Rep. Organization for Economic Cooperation and Development, DAS/CSI/ $68.27,192 \mathrm{p}$. 